\title{
DASAR-DASAR PENDIDIKAN ANAK USIA DINI DALAM PEMIKIRAN KI HADJAR DEWANTARA
}

\author{
Diana Dwi Jayanti a,1 \\ ${ }^{a}$ Universitas Islam Lamongan Indonesia \\ ${ }^{1}$ dianadj1187@gmail.com
}

\begin{tabular}{l}
\hline Informasi artikel \\
\hline Received : \\
Agust 15, 2018. \\
Revised: \\
Agust 27, 2018. \\
Publish: \\
September 09, 2018. \\
Kata kunci: \\
Dasar-dasar Pendidikan; \\
Pendidikan Anak Usia \\
Dini; \\
Ki Hadjar Dewantara
\end{tabular}

Keywords:

Basics of Education;

Early Childhood

Education;

Ki Hadjar Dewantara

\begin{abstract}
ABSTRAK
Di tengah keringnya pelaksanaan praksis pendidikan dari ruh landasan filosofis, pemikiran-pemikiran Ki Hadjar Dewantara yang sangat mendasar, mendalam, dan visioner tentang pendidikan khususnya dalam konteks budaya Indonesia, dirasa masih sangat relevan untuk dikaji lebih jauh, sehingga dapat dipahami, diinternaslisasi kemudian dijadikan sebagai landasan filosofis pelaksanaan praksis pendidikan di Indonesia. Penelitian ini menghasilkan pembahasan tentang filsafat pendidikan, serta dapat menjadi salah satu alternatif kajian filosofis pendidikan di Indonesia, diantara banyaknya referensi-referensi yang berasal dari pemikiran para tokoh pendidikan dari luar negeri yang tentunya perlu adaptasi dan modifikasi jika ingin dijadikan sebagai dasar pijakan praksis pendidikan di Indonesia.
\end{abstract}

This work is licensed under a Creative Commons Attribution-ShareAlike 4.0 International License. Allows readers to read, download, copy, distribute, print, search, or link to the full texts of its articles and allow readers to use them for any other lawful purpose. 


\section{PENDAHULUAN}

Pendidikan dan pengajaran merupakan suatu usaha yang dilakukan untuk menyiapkan masa depan manusia, menumbuhkan harkat dan martabatnya, menjadi lebih baik dan bermanfaat sebagai individu maupun anggota masyarakatnya. Setiap kelompok masyarakat, mulai dari kelompok masyarakat terkecil, yakni keluarga, hingga negara dan bangsa, pasti memiliki visi pendidikannya masing-masing, baik tersadari maupun tidak, tertulis atau tidak. Hal ini karena melalui proses pendidikan juga terjadi suatu proses yang disebut sebagai pembudayaan.

Mengingat pentingnya peran dan fungsi pendidikan bagi kehidupan manusia dan kemanusiaan, tentu dalam praksisnya, pendidikan tidak bisa dilakukan secara asal, perlu adanya landasan atau rambu-rambu terkait dengan apa dan bagaimana seharusnya pendidikan dilaksanakan. Lebih lanjut Biesta (2015, dalam Shihab, 2015) menggambarkan pendidikan sebagai proses yang penuh resiko jika tidak dipikirkan secara matang, karena melibatkan proses interaksi antar manusia yang dinamis. Dalam proses pendidikan, input dan proses yang telah terstandar, belum menjadi jaminan akan menghasilkan output yang sama sebagaimana yang diharapkan. Banyak sekali faktor yang melingkupi manusia. Hal ini menjadikan hubungan sebab akibat linier yang berkaitan dengan tercapainya tujuan pendidikan tidak serta merta tercipta, sehingga pertanyaan tentang efektifitas proses dan cara mencapai tujuan tidak dapat berhenti dan harus selalu berkembang dengan dijabarkan menjadi pertanyaan terkait dengan efektif "untuk apa", "bagi siapa", dan "di mana" (Shihab, 2015).

Landasan pendidikan tergolong ke dalam jenis landasan yang bersifat konseptual. Landasan yang bersifat konseptual pada dasarnya identik dengan asumsi, yaitu suatu gagasan, kepercayaan, prinsip, pendapat atau pernyataan yang sudah 
dianggap benar, yang dijadikan titik tolak dalam rangka berpikir (melakukan suatu studi) dan/atau dalam rangka bertindak (melakukan suatu praktik). Asumsi-asumsi yang menjadi titik tolak dalam rangka pendidikan berasal dari berbagai sumber, dapat bersumber dari agama, filsafat, ilmu, dan hukum atau yuridis. Berdasarkan sumbernya jenis landasan pendidikan dapat diidentifikasi dan dikelompokkan menjadi: 1) landasan religius pendidikan, 2) landasan filosofis pendidikan, 3) landasan ilmiah pendidikan, dan 4) landasan hukum/yuridis pendidikan. Dua landasan pertama bisa digambarkan sebagai pondasi bangunan, dan dua landasan berikutnya sebagai tiang pancang dalam suatu bangunan sistem pendidikan.

Berbicara praksis pendidikan di Indonesia, kita tidak bisa memungkiri, masih banyak 'pekerjaan rumah' yang perlu untuk difikirkan bersama. Beberapa isu permasalahan pendidikan di Indonesia yang perlu untuk difikirkan bersama antisipasi dan alternatif jalan keluarnya, seperti misalnya: 1) Implementasi Ujian Nasional dan segala bentuk penekanan, 2) semakin maraknya budaya kekerasan dan diskriminasi dalam praktek pendidikan, 3) kurang matangnya pembentukan karakter dan kepribadian luhur dalam diri siswa, dan lain sebagainya. Munculnya beberapa permasalahan tersebut, jika dirunut kebelakang, kemudian memunculkan suatu pertanyaan mendasar terkait adakah landasan dasar pendidikan yang menjadi acuan terlaksanananya praksis pendidikan di Indonesia. Secara tersurat, landasan ilmiah pendidikan, dan landasan hokum/yuridis pendidikan, bisa dikatakan tidak ada masalah. Namun, terkait dengan dua landasan awal, yakni landasan filosofis/religious, sepertinya perlu dikaji lebih lanjut. 
Suparno, (2012), dalam makalahnya menganalisis suatu pertanyaan tentang ada tidaknya landasan filsafat pendidikan dalam praksis pendidikan di Indonesia. Dalam makalah yang disampaikan pada seminar pendidikan yang dilaksanakan oleh Kompas di Jakarta, tanggal 23 April 2012 tersebut, dapat disimpulkan bahwa tidak ada dokumen filsafat pendidikan Indonesia yang diresmikan oleh pemerintah dan dijadikan pedoman serta landasan dalam praktek pendidikan di Indonesia sekarang ini. Bahkan Dokumen rasional yang mendasari UU Sisdiknas saja tidak disertakan dalam UU Sisdiknas, sehingga orang hanya tahu undang-undangnya yang tertulis, tetapi tidak tahu mengapa undang-undang itu akhirnya dirumuskan demikian dan diterima. Akibatnya, dalam membaca UU Sisdiknas, kita merasa kering dan kurang berani untuk menganalisis secara lebih mendalam. Dengan tidak adanya dokumen filosofi tertulis yang dapat dipakai pegangan, maka akibatnya adalah dalam praktek pendidikan orang dapat mengembangkan filsafatnya sendiri-sendiri, yang penting tidak melanggar UU yang ada. Akibat tidak adanya dokumen tertulis, maka juga menjadi cukup sulit mencari titik temu dalam pemecahan permasalahan pendidikan yang lebih mendalam.

Suparno (2012), juga melakukan analisis tentang bagaimana realita praktek pendidikan nasional yang ada di lapangan kemudian menggali filsafat pendidikan apa yang ada di baliknya. Dalam analisannya, Suparno (2012), membatasi pada; 1) praktek pendidikan yang terjadi sejak adanya UU Sisdiknas 2003, dan 2) melakukan tinjauan filosofis dengan menganalisis tujuan pendidikan nasional dan implementasinya di lapangan. Hasil analisis tersebut menggambarkan bahwa rumusan tujuan pendidikan nasional yang begitu indah itu dalam praktek sering tidak tercapai atau terjadi karena rumusan yang indah itu kurang dijabarkan dalam indikator yang dapat diukur atau dipantau di lapangan. Misalnya saja "beraklak mulia", sering tidak dimengerti secara 
jelas di lapangan, sehingga dalam proses pendidikan tidak dapat diukur dengan lebih jelas. Dalam praktek pendidikan yang ukurannya sudah lebih jelas adalah kompetensi dalam bidang pengetahuan atau kognitif, sedangkan dalam segi karakter, beriman, takwa, akhlak, berbudi luhur, demokratis dll masih banyak yang kabur atau bahkan tidak terukur. Akibatnya proses pendidikan belum sungguh-sungguh membantu tercapai tujuan pendidikan yang lebih utuh. Selain itu program-program pendidikan yang dicanangkan oleh pemerintah dianggap justru kurang mendukung tujuan pendidikan nasional yakni mengembangkan manusia Indonesia secara utuh.

Kurang terdukungnya cita-cita pendidikan nasional ini dapat dilihat pada beberapa hal misalnya: 1) terlalu banyaknya intervensi dalam kurikulum sekolah oleh pihak pemangku kebijakan yang terkesan tambal sulam, tanpa pertimbangan pada apakah tambahan-tambahan tersebut sungguh penting dan memang belum tercakup dalam kurikulum secara keceluruhan, 2) kecenderungan proses pendidikan yang lebih menekankan pada hasil belajar yang bersifat kognitif, dan kurangnya proses yang mengarah pada pengembangan karakter, nilai, dan moral, 3) pengaplikasian kurikulum yang relatif sama dengan pendekatan yang cenderung berpusat pada guru. Perlu beberapa usaha yang perlu menjadi pertimbangan pemangku kebijakan untuk mengembangkan pendidikan kedepan.

Berdasarkan penjelasan latar belakang diatas, dalam tulisan ini penulis mencoba memberikan sedikit pemaparan tentang salah satu landasan pemikiran filosofis pendidikan, khususnya terkait dengan konteks pendidikan di Indonesia, dari salah satu tokoh pendidikan bangsa, Ki Hadjar Dewantara. Pemikiran-pemikiran Ki Hadjar Dewantara tentang pendidikan, khususnya dalam konteks Indonesia, dirasa relevan untuk dijadikan sebagai landasan filosofis pelaksanaan praksis pendidikan di 
Indonesia. Hal ini karena pemikiran-pemikiran tersebut lahir dan diramu dalam konteks kebudayaan bangsa Indonesia yang khas. Melalui tulisan ini diharapkan dapat memberikan tambahan wacana dan sudut pandang pembahasan tentang filsafat pendidikan, serta dapat menjadi salah satu alternatif kajian filosofis pendidikan di Indonesia, diantara banyaknya referensi-referensi yang bersumber dari luar negeri.

\section{PEMBAHASAN}

\section{Pandangan Dasar tentang Jiwa Anak}

Menjelaskan tentang hal ihwal pendidikan, pemikiran Ki Hadjar Dewantara, dapat dikatakan sangat mendalam dan menyeluruh. Hal ini dapat dilihat dari adanya satu bahasan tersendiri terkait dengan subyek pendidikan, yakni anak. Tidak hanya dari salah satu aspek perkembangan saja, namun lebih mendalam dimulai dari pembahasan mengenai dasar jiwanya peserta didik. Menjabarkan tentang hal jiwa ini memang Ki Hadjar Dewantara mengacu dan meramunya dari pandangan-pandangan tokoh filosofis terdahulu mulai dari Aristoteles hingga pandangan-pandangan tokoh dalam kajian psikologi seperti Freud.

Dalam tulisannya yang dimuat di majalah Keluarga, Tahun ke-1 No.6 - Mei 1937. Ki Hadjar menjelaskan pemikiran beliau tentang apa itu jiwa. Secara umum, jiwa dapat dimengerti sebagai kekuatan yang menjadi penggerak hidup manusia. Selain itu kata jiwa juga dapat dipahami sebagai kumpulan kekuatan atau kecakapan dalam batin manusia, seperti halnya pikiran, perasaan, kemauan, serta kesadaran. Sehingga jika disimpulkan, pengertian tersebut dapat dirumuskan bahwa jiwa merupakan kekuatan dalam diri manusia yang menggerakkan kehidupan manusia, menyebabkan manusia dapat berpikir, berperasaan, dan berkehendak (berbudi), serta menyebabkan orang mengerti atau sadar terhadap segala gerak jiwanya. 
Pada tulisannya yang lain, yakni dalam majalah Pusara, Agustus 1933, Jilid III, No.11, Ki Hadjar Dewantara juga menjelaskan beberapa konsepsi yang berhubungan dengan konsep jiwa, seperti watak dan karakter. Dalam tulisannya tersebut beliau memaparkan bahwa watak atau karakter merupakan segala tabiat/sifat-sifat khas yang relatif menetap pada diri tiap manusia, sehingga hal itu menjadi identitas khusus yang membedakan antara manusia satu dengan manusia lain. Karakter manusia muncul sebagai suatu potensi dasar dalam diri manusia yang berhubungan dengan sifat herediter, kemudian berkembang, dan terpola melalui proses pematangan dalam belajar dan pengalaman. Pada tulisan beliau yang membahas tentang watak dan karakter ini, beliau juga dijelaskan keterkaitannya dengan jiwa. Karakter merupakan bagian dari jiwa yang berfungsi sebagai pembanding antara kehidupan batiniah dengan perbuatan lahir seseorang. Kematangan karakter mencerminkan kehidupan batiniah yang positif dan tercermin dalam perilaku lahir yang positif.

Berbicara tentang dasar jiwa anak, Ki Hadjar menjelaskan bahwa yang dimaksud sebagai 'dasar jiwa' merupakan kondisi dasar jiwa seseorang yang asli sesuai kodrat lahir sebelum dipengaruhi oleh hal-hal di luar diri. Keadaan jiwa yang seperti itu dibawa oleh seorang anak ketika lahir. Pada konteks pendidikan terdapat 3 asumsi aliran teoritis yang menjelaskan tentang dasar jiwa ini. Pandangan pertama biasa dikenal dengan teori Tabula Rasa yang munculnya dipelopori oleh John Lock, salah satu tokoh pemikir dan filsuf pada masa tahun 1632 - 1704 M. Teori ini melihat dasar jiwa seorang manusia yang baru lahir diibaratkan sebagai kertas atau kain putih yang kosong yang belum ada tulisan atau noda diatasnya. Hal ini berimplikasi pada pandangan bahwa lingkungan, termasuk didalamnya proses pendidikan, memiliki pengaruh utama dalam membentuk watak, budi, dan karakter seseorang. 
Pandangan kedua dikenal dengan aliran nativisme/pesimisme/negative. Lairan ini memiliki asumsi bahwa setiap manusia yang lahir ke dunia telah memiliki kodrat bawaan yang melekat. Manusia yang lahir memiliki kodrat yang cenderung positif maupun negative. Kodrat bawaan ini juga sangat dipengaruhi oleh aspek hereditas yang diturunkan melalui gen orang tua - orang tua sebelumnya. Aliran ini memandang bahwa pengaruh lingkungan, pengalaman, dan proses pendidikan tidak memiliki pengaruh signifikan bagi perubahan karakter dan perilaku seseorang. Jika seseorang terlahir dengan kecenderungan dasar jiwa negative, maka lingkungan, pengalaman dan proses pendidikan hanya dapat mengawasi dan mengamati agar potensi negatif dalam diri individu tidak semakin menguat dan muncul sebagai manifestasi perilaku dan sikap. Jika seseorang terlahir dengan kecenderungan dasar jiwa yang positif, maka lingkungan, pengalaman, dan proses pendidikan berfungsi sebagai penangkal pengaruh negative yang berasal dari luar supaya tidak masuk pada jiwa seseorang. Pandangan ketiga biasa disebut sebagai aliran teori konvergensi. Teori ini menjadi penengah dari dua teori sebelumnya yang sifatnya cenderung berat sebelah dalam memandang kondisi dasar jiwa seorang individu. Aliran ini memandang bahwa seseorang lahir tidak dalam kondisi kosong, setiap manusia membawa kodrat kelahirannya, namun kodrat dasar jiwa tersebut tidak masih memiliki peluang untuk dikembangkan, diperkuat, bahkan dihilangkan melalui interaksi manusia tersebut dengan lingkungan, pengalaman, maupun proses pendidikan. Aliran ini sama-sama memandang penting pengaruh aspek hereditas bawaan dan lingkungan dalam membentuk, mengembangkan, memperkuat baik buruknya dasar jiwa seseorang, yang kemudian berpengaruh pada manifestasi sikap dan perilaku lahirnya. 


\section{Fungsi, tujuan pendidikan serta Bagaimana seharusnya pendidikan yang tidak menyalahi kodrat jiwa anak}

Pada bukunya bagian I yang bertajuk Pendidikan, Ki Hadjar merumuskan fungsi dan tujuan pendidikan sebagai berikut:

“... yang dinamakan pendidikan yaitu tuntunan didalam hidup tumbuhnya anak-anak. Adapun maksudnya pendidikan yaitu: menuntun segala kekuatan kodrat yang ada pada anak-anak itu, agar mereka sebagai manusia dan sebagai anggota masyarakatnya dapatlah mencapai keselamatan dan kebahagiaan yang setinggi-tingginya."

Berdasarkan rumusan tersebut dapat dijelaskan bahwa pendidikan berfungsi hanya sebagai tuntunan seseorang dalam proses tumbuh kembang kehidupannya. Dan tujuan dari pendidikan adalah agar anak-anak dalam kehidupannya sebagai seorang individu maupun anggota masyarakat dapat mencapai well being, yakni kondisi yang oleh Ki Hadjar disebut sebagai selamat dan bahagia.

Sebagai suatu tuntunan hidup, proses pendidikan, termasuk didalamnya halhal yang diupayakan oleh pendidik dalam proses pembelajaran lebih tepat disebut sebagai proses mengarahkan, menumbuhkan potensi-potensi yang telah terkodrat dalam diri anak, bukan mencetak, membentuk, atau istilah-istilah sejenis lainnya. Di buku yang sama, Ki Hadjar juga menjelaskan:

"Hidup dan tumbuhnya anak-anak itu terletak di luar kecakapan dan kehendak kita kaum pendidik. Anak-anak itu sebagai makhluk, sebagai manusia, sebagai benda hidup, teranglah hidup dan tumbuh menurut kodratnya sendiri”.

Berdasarkan tulisan tersebut dapat dikatakan bahwa asumsi dasar yang dianut oleh beliau lebih mengarah pada pandangan bahwa anak yang terlahir ke dunia 
bukanlah kertas kosong. Anak mempunyai kodratnya sendiri sebagai makhluk Tuhan, yang tidak bisa diubah sesuai keinginan pendidik. Pendidik hanya bisa mengarahkan tumbuh kembangnya kodrat tersebut. Ibarat sebuah benih, jika seorang anak sudah terlahir dengan kodrat sebagai benih mangga, maka pendidik tidak akan bias mengubah benih mangga tersebut menjadi pisang atau tanaman lainnya. Hal-hal yang dapat dilakukan oleh pendidik hanya sebatas menyediakan tanah yang subur, memupuk, dan menyiram benih tersebut agar tumbuh menjadi mangga dengan kualitas super.

Tercermin dalam tulisan-tulisannya, dapat dikatakan, Ki Hadjar merupakan salah/ satu tokoh yang setuju dengan pandangan konstruktivisme dalam pendidikan. Misalnya/ saja yang tertuang dalam buku Peringatan 30 Tahun Taman-Siswa (19221952), disebutkan bahwa:

“...Kemerdekaan hendaknya dikenakan terhadap caranya anak-anak berpikir, yaitu jangan selalu dipelopori atau disuruh mengakui buah pikiran orang lain, tetapi biasakanlah anak-anak mencari sendiri segala pengetahuan dengan menggunakan pikirannya sendiri."

Berdasarkan tulisan tersebut dapat dikatakan bahwa dalam proses belajar, seorang anak diasumsikan sebagai subyek yang aktif, yang memiliki kemampuan untuk membangun dan mengkonstruksi pengetahuan dan pemahamannya. Menurut pandangan ini, setiap anak telah membawa skema-skema pengetahuan bawaan, yang perlu untuk dikembangkan menjadi pola pengetahuan dan pemahaman baru melalui proses mengkonstruksi dalam belajar. Belajar dan pendidikan bukanlah proses memasukkan pengetahuan ke diri anak. Sehingga tugas seorang pendidik lebih diarahkan pada proses mendampingi, memfasilitasi, dan membantu anak dalam 
membangun pengetahuan dan otentisitas pemahamannya tentang informasi-informasi baru yang dihubungkan dengan pengetahuan dan pemahaman yang dimiliki sebelumnya.

\section{Pendidikan Anak Usia Dini dalam Pandangan Pemikiran Ki Hadjar Dewantara}

Mendasarkan pada kajian ilmu psikologi dan untuk keperluan pendidikan, Ki Hadjar membagi usia peserta didik menjadi 3 masa, yakni:

a. Masa sejak lahir hingga usia tujuh tahun

b. Masa anak-anak muda, sejak usia 7 hingga 14 tahun, dan

c. Masa dewasa, 14 hingga 21 tahun

Dari ketika pembagian tahapan usia tersebut, Ki Hadjar menekankan pentingnya periode usia pertama, yakni usia pra kelahiran hingga usia 7 tahun. Hal ini karena hal-hal dari lingkungan (luar diri) yang masuk pada jiwa anak, akan turut serta mempengaruhi terbentuknya dasar jiwa anak. Pendapat tersebut dipengaruhi oleh dua tokoh pendidikan anak usia dini yakni Maria Montessori dan Karl Groos. Periode tahapan usia yang pertama (usia 0 sampai 7 tahun) dibagi lagi menjadi dua, yakni usia 0 hingga 3 tahun, dan usia 3 hingga 7 tahun. Pembagian usia ini berimplikasi pada pandangan tentang bagaimana pendidikan diberikan kepada anak-anak. Ki Hadjar menjelaskan bahwa pada prinsipnya $0-3$ tahun, proses pendidikan lebih cenderung diarahkan pada pemeliharaan dan pengembangan aspek jasmani indrawi. Pendidikan juga dapat mulai diarahkan pada pembiasaan-pembiasaan yang berhubungan dengan kemampuan mengatur dan menolong diri sendiri, sehingga dapat terbentuk dan 
perkembang kemandirian dalam merawat diri sendiri. Kemudian pada usia 3 - 7 tahun, ketika kemampuan intelektual mulai lebih berkembang, mulailah proses pendidikan diarahkan pada pembiasaan yang lebih disadari dan tanggung jawab. Pada masa ini sudah mulai muncul dan berkembang kesadaran pada jiwa anak, serta mulai berkembang secara lebih pesat hal-hal yang berhubungan dengan fungsi-fungsi otak, sehingga hal-hal yang berasal dari luar diri anak lebih mudah terserap, dan jika melekat akan mewarnai terbentuknya dasar jiwa dan karakter pada masa perkembangan selanjutnya.

Terdapat tiga ciri atau karakteristik jiwa anak-anak usia 3-7 tahun yang dijelaskan oleh Ki Hadjar, yakni: a) mulai muncul kegemaran berbicara, bertanya, mendengarkan cerita dan lain. Munculnya kesenangan ini dipengaruhi oleh mulai berkembangnya aspek intelektual yang berhubungan dengan imajinasi. b) mulai muncul kegemaran seperti corat-coret, menuliskan tulisan dalam bermacam bentuk, dan menyanyi sesuai kehendak sendiri, yang mungkin orang lain kurang bisa memahaminya. Selain itu juga mulai muncul ketetarikan pada berbagai macam warna serta musik atau suara-suara pada umumnya. Proses pendidikan pada usia 3 - 7 tahun, perlu dilaksanakan dengan cara. c) muncul kegemaran untuk bergerak secara aktif. Hal ini dapat kita lihat pada pola aktifitas anak-anak di usia tersebut yang seolah-olah tidak bisa diam dan selalu ingin beraktifitas dan bermain. Sebagai orangtua maupun pendidik, sudah seyogyanya, dapat mengenali dan memahami karakteristikkarakteristik dasar jiwa anak-anak tersebut, sehingga mereka dapat menyediakan ruang dan sarana yang tepat untuk menumbuh kembangkan potensi yang ada pada diri anak. 
Dalam tulisannya, Ki Hadjar juga membahas satu tema tersendiri yang membahas tentang permainan anak-anak. dalam tulisannya tersebut, beliau menekankan bahwa permainan atau aktifitas bermain pada anak-anak memiliki kedudukan dan arti yang sangat penting. Bahkan dituliskan bahwa ketika anak-anak tidak menunjukkan kegemaran bermain, hal itu bisa menjadi salah satu gejala kurang baiknya kondisi jasmani dan juga rohaninya. Hal ini senada dengan pandangan yang dikemukakan oleh Frobel, Montessori, serta Karl Groos. Ketiga tokoh ini meletakkan permainan atau aktivitas bermain pada anak-anak sebagai inti penting serta terimplimentasi secara nyata pada metode-metode pendidikan anak usia dini yang dicetuskannya. Frobel misalnya dengan semboyan "dari natur ke arah kultur", menggunakan permainan dan nyanyian anak-anak pada metode pendidikannya. Kemudian Montessori, dalam berbagai percobaan ketika menyusun dan merumuskan metode pendidikannya, ia menemukan berbagai permainan sensori-motorik yang sangat bermanfaat untuk mengembangkan fungsi-fungsi budi pekerti sebagai bagian untuk mempersiapkan dan melatih diri anak menghadapi tugas-tugas perkembangan selanjutnya.

Terdapat berbagai manfaat permainan yang dirumuskan oleh Ki Hadjar, antara lain:

a. Menajamkan pikiran, memperhalus rasa, memperkuat kemauan, serta mendidik sikap jiwa untuk tetap terus sanggup berjuang sampai tercapainya tujuan.

b. Mengembangkan kesadaran tentang kekuatan lahir dan batin pada diri sendiri.

c. Mengembangkan kemampuan menyesuaikan diri terhadap situasi-situasi baru dan tak terduga. 
d. Mengembangkan kemampuan mengevaluasi dan mengoreksi kesalahan atau kekurangan pada diri sendiri.

e. Mendidik perasaan diri dan sosial, disiplin diri, ketertiban, komitmen terhadap peran dan tanggung jawab terhadap tugas.

f. Berlatih dan membiasakan berpikir secara praktis sesuai kondisi nyata, berpikir kritis, cerdik, dan bijaksana dalam memilih sikap yang tepat atas situasi dan kondisi yang dihadapi.

\section{PENUTUP}

Mengingat pentingnya peran dan fungsi pendidikan bagi kehidupan manusia dan kemanusiaan, tentu dalam praksisnya, pendidikan tidak bisa dilakukan secara asal. Perlu adanya landasan filosofis yang mendasar sebagai acuan dan pedoman sehingga pelaksanaan praksis pendidikan memiliki arah, maksud, dan tujuan yang jelas. Berdasarkan hasil kajian Suparno, (2012), yang disampaikan dalam seminar pendidikan nasional yang diselenggarakan oleh Kompas, dijelaskan bahwa tidak ada dokumen filsafat pendidikan Indonesia yang diresmikan oleh pemerintah dan dijadikan pedoman serta landasan dalam praktek pendidikan di Indonesia sekarang ini. Dengan tidak adanya dokumen filosofi tertulis yang dapat dipakai pegangan, maka akibatnya adalah dalam praktek pendidikan orang dapat mengembangkan filsafatnya sendiri-sendiri, yang penting tidak melanggar UU yang ada. Akibat tidak adanya dokumen tertulis, maka juga menjadi cukup sulit mencari titik temu dalam pemecahan permasalahan pendidikan yang lebih mendalam.

Selanjutnya rumusan dasar pelaksanaan pendidikan nasional yang tercermin dalam UU Sisdiknas 2003, dirasa sangat indah namun sekaligus kurang membumi. Rumusan tujuan pendidikan nasional yang begitu indah itu dalam praktek sering tidak 
tercapai atau terjadi karena rumusan yang indah itu kurang dijabarkan dalam indikator yang dapat diukur atau dipantau di lapangan. Akibatnya proses pendidikan belum sungguh-sungguh membantu tercapai tujuan pendidikan yang lebih utuh. Selain itu program-program pendidikan yang dicanangkan oleh pemerintah dianggap justru kurang mendukung tujuan pendidikan nasional yakni mengembangkan manusia Indonesia secara utuh.

Sebagai salah satu tokoh pendidikan yang sangat berpengaruh di Indonesia, Ki Hadjar Dewantara memiliki pemikiran-pemikiran yang sangat visioner tentang pendidikan dalam konteks ke-Indonesiaan. Hasil pemikiran-pemikiran tersebut, yang juga telah teraplikasi dalam pelaksanaan pendidikan di Perguruan Taman Siswa, sudah seyogyanya mendapat perhatian lebih untuk dikaji, dipahami, untuk kemudian dapat dijadikan sebagai landasan filosofis pelaksanaan pendidikan di Indonesia. Meskipun mendapatkan pengaruh dari pemikiran tokoh pendidikan luar negeri, pemikiranpemikiran beliau telah dimasukkan dalam konteks kebudayaan yang khas di Indonesia. Hal ini menjadi salah satu aspek yang seharusnya dijadikan pertimbangan untuk menjadikan pemikiran beliau sebagai referensi utama dalam kajian filsafat pendidikan di Indonesia diantara referensi-referensi filsafat pendidikan yang berasal dari luar negeri. Hal ini mengingat bahwa untuk menerapkan pemikiran yang berasal dari luar negeri perlu adanya adaptasi dan modifikasi sehingga bisa sesuai dengan konteks kultur praksis pendidikan di Indonesia.

Adapun beberapa prinsip dasar pemikiran Ki Hadjar Dewantara yang penting untuk dipahami sebagai dasar pelaksanaan praktek pendidikan antara lain: 
1. Terkait dengan dasar jiwa anak, setiap anak memiliki kodrat lahir atau potensi khas yang tidak dapat dihilangkan atau diubah oleh proses pendidikan. Pendidik hanya dapat mengarahkan dan menumbuhkan secara optimal potensi khas tersebut menjadi kemampuan, perilaku, dan kebiasaan nyata yang positif.

2. Proses belajar dan pendidikan bukanlah proses mengisi gelas kosong, tetapi menumbuhkan benih (potensi khas anak), melalui penyediaan lingkungan dan proses fasilitasi yang sesuai (kodrat/potensi khas anak) secara optimal. Fungsi dan tujuan pendidikan adalah hanya sebagai tuntunan seseorang dalam proses tumbuh kembang kehidupannya supaya dapat mencapai kehidupan yang selamat dan bahagia sebagai individu maupun anggota masyarakat.

3. Proses pendidikan sudah seharusnya dilakukan sejak usia dini dengan mempertimbangkan karakteristik-karakteristik perkembangan jiwa peserta didik. Harus ada pemahaman tentang metode dan cara mendidikan yang berbeda-beda sesuai karakteristik perkembangan jiwa tersebut.

4. Pentinnya bermain dan permainan dalam pendidikan anak usia dini. Bermain dan permainan menjadi hal sangat penting dan tidak dapat dihilangkan dalam proses pendidikan anak usia dini. Hal ini karena bermain dan permainan sesuai dengan karakteristik kodrat jiwa anak yang aktif dan konstruktif. Melalui bermain dan permainan anak dapat mengeksplorasi dan mempelajari banyak hal, baik itu halhal yang terkait dirinya sendiri maupun hal-hal yang terkait dengan dunia di luar dirinya. 


\section{REFERENSI}

Bukik Setiawan. Anak Bukan Kertas Kosong. (Jakarta: Panda Media, 2015)

Ki Hadjar Dewantara. Karya Ki Hadjar Dewantara Bagian I: Pendidikan. (Yogyakarta: Majelis Luhur Taman Siswa, 1977) . Menuju Manusia Merdeka. (Yokyakarta: Leutika, 2009)

Najeela Shihab. Diferensiasi; Memahami Pelajar untuk Belajar Bermakna \& Menyenangkan. (Jakarta: Penerbit Literati, 2015)

Paul Suparno, Filsafat Pendidikan dalam Praksis Pendidikan Nasional, (Seminar Pendidikan KOMPAS, 23 April 2013) 